\title{
Cytosine methylation prevents binding to DNA of a HeLa cell transcription factor required for optimal expression of the adenovirus major late promoter
}

\author{
Fujiko Watt and Peter L. Molloy ${ }^{1}$ \\ CSIRO Division of Biotechnology, Laboratory for Molecular Biology, P.O. Box 184, North Ryde, NSW 2113, Australia
}

\begin{abstract}
Cytosine methylation within CpG dinucleotides has been implicated in the regulation of gene expression in vertebrates and, in some cases, has been shown to be causative in repression of transcription. We have examined whether methylation of $\mathrm{CPG}$ dinucleotides located within the binding site for a specific transcription factor, MLTF or USF, affects its binding to DNA. This HeLa cell factor binds to the adenovirus major late promoter (AdMLP), as well as endogenous cellular genes, and stimulates transcription in an in vitro assay. Synthetic oligonucleotides in which 5-methylcytosine replaces cytosine at specific sites were used to generate duplex DNAs, and the formation of complexes of these oligomers with MLTF was studied using a gel retardation assay. Methylation at a CPG site centrally located within the binding site strongly inhibited complex formation, whereas methylation at a site 6 bases away had no demonstrable effect. Methylation at the central site was also shown to inhibit specific transcription in vitro from the AdMLP. Methylation at the central site on only one strand caused a partial inhibition of binding, the effect being greater when the noncoding strand was methylated. The results indicate that in some cases, site-specific methylation may inhibit gene expression directly by blocking binding to DNA of factors required for optimal transcription. Along with other recent findings, they suggest an interplay between DNA methylation and transcription factors in the regulation of gene expression.
\end{abstract}

[Key Words: DNA methylation; transcription factor; adenovirus major late promoter]

Received October 5, 1987; revised version accepted July 6, 1988.

Methylation of cytosine in $\mathrm{CpG}$ dinucleotides is often associated with the repression of specific gene expression (for reviews, see Doerfler 1983; Cedar 1984). Two types of experiments have demonstrated that methylation can cause inhibition of transcription of a number of genes. Loss of methylation through treatment with 5-azacytidine has been shown to activate expression of a number of transcriptionally inactive genes. More directly, expression of methylated DNA /generally obtained by the incorporation of 5-methyl dCTP during DNA synthesis or through the use of bacterial methyltransferase enzymes) has been studied following its introduction into cells. Such methylated DNA has been shown to be transcriptionally repressed compared with its unmethylated counterpart. In such cases, critical methylation sites typically have been located in or around promoter sequences at the $5^{\prime}$ end of the genes (Busslinger et al. 1983; Kruczek and Doerfler 1983; Langner et al. 1984; Keshet et al. 1985; Feenstra et al. 1986).

\footnotetext{
${ }^{1}$ Corresponding author.
}

Recent work has demonstrated that promoter regions contain sequences that bind both specific and general factors important for gene activity and regulation (e.g., see Yamamoto 1985; McKnight and Tjian 1986). One mechanism by which DNA methylation might inhibit transcription is by interfering with the binding of transcription factors to such sites.

We have examined whether methylation at individual CpG dinucleotides within the adenovirus major late promoter (AdMLP) can influence transcription factor binding. Optimal expression both in vitro and in vivo from the AdMLP is dependent on two sequence regions, the TATA box region and a region from bases -66 to -50 [the upstream promoter element, (UPE)] (Hen et al. 1982; Jove and Manley 1984; Miyamoto et al. 1984; Yu and Manley 1984). In vitro experiments have shown that a specific transcription factor, MLTF or USF, binds to this region (Carthew et al. 1985; Miyamoto et al. 1985; Sawadogo and Roeder 1985a; Shi et al. 1986) and causes a stimulation of transcription. MLTF is present in uninfected HeLa cells and, thus, is likely to be involved in expression of endogenous cellular genes. Homologies to the MLTF-binding site have been identified in a number 
of promoters from cellular genes (Sawadogo and Roeder 1986), and MLTF has been shown to bind to and stimulate transcription from mouse metallothionein I and rat $\gamma$-fibrinogen genes (Carthew et al. 1987; Chodosh et al. 1987). The binding region for MLTF in the AdMLP contains two CpG dinucleotides at positions -58 and -52 , which could potentially be methylated in mammalian cells. Enzymatic methylation of sites -52 and -12 in the AdMLP, using HpaII and HhaI methylases, respectively, has been shown previously not to have a demonstrable effect on transcription in vitro (Jove et al. 1984). Here, we examine the effects of methylation of cytosines at the -58 and -52 sites on binding of MLTF to the AdMLP.

\section{Results}

\section{Methylation at a single CpG site inhibits MLTF binding}

A map and sequence of the AdMLP indicating the positions of the -58 and $-52 \mathrm{CpG}$ sites are shown in Figure 1. Because the CpG site at -58 could not be specifically methylated using commercially available enzymes, DNA fragments methylated at this site were obtained by the specific incorporation of 5-methylcytosine during oligonucleotide synthesis. Synthetic DNA fragments $(100 \mathrm{bp}$ ) were made by the end-filling of overlapping oligonucleotides (see Fig. 1). Methylation at the $-52 \mathrm{CpG}$ site was achieved either through oligonucleotide synthesis or through the use of HpaII methylase.
Binding of these DNAs to the MLTF has been studied using a gel retardation assay in which unbound DNA fragments are separated from DNA-MLTF complexes (Fig. 2). DNase I digestion experiments (Watt and Molloy 1988) have confirmed that the UPE is protected from digestion in the DNA-MLTF complex. In Figure 2A, it is clear that MLTF binds to the unmethylated DNA (O) and binds with much reduced efficiency to DNA methylated on both strands at both -58 and -52 sites [O $[58$, 52)]. The low level of binding to the methylated DNA, visible on long exposures of the gel in Figure 2A, had reached a maximum by $10 \mathrm{~min}$, indicating that the difference reflects a lower amount of MLTF bound at equilibrium rather than a slower rate of association. Restriction enzyme fragments methylated at the HpaII site $(-52)$ and synthetic DNA methylated at the -58 site were used to test relative effects of the methylation of each site on MLTF binding. From the results of Figure 2, $B$ and $C$, it can be concluded that the inhibition of binding is due to methylation at the -58 site. In a number of experiments (e.g., Fig. 2B), no significant effect of methylation at the -52 site has been observed on the binding of MLTF. This is consistent with the lack of effect of methylation at this site on a transcription in vitro (Jove et al. 1984). In the experiment shown in Figure 2C, an unmethylated 528-bp fragment (L) was coincubated with the oligonucleotide DNA methylated at the $-58 \mathrm{CpG}$ site to act as a positive binding control in case of possible inhibitors that may have been present

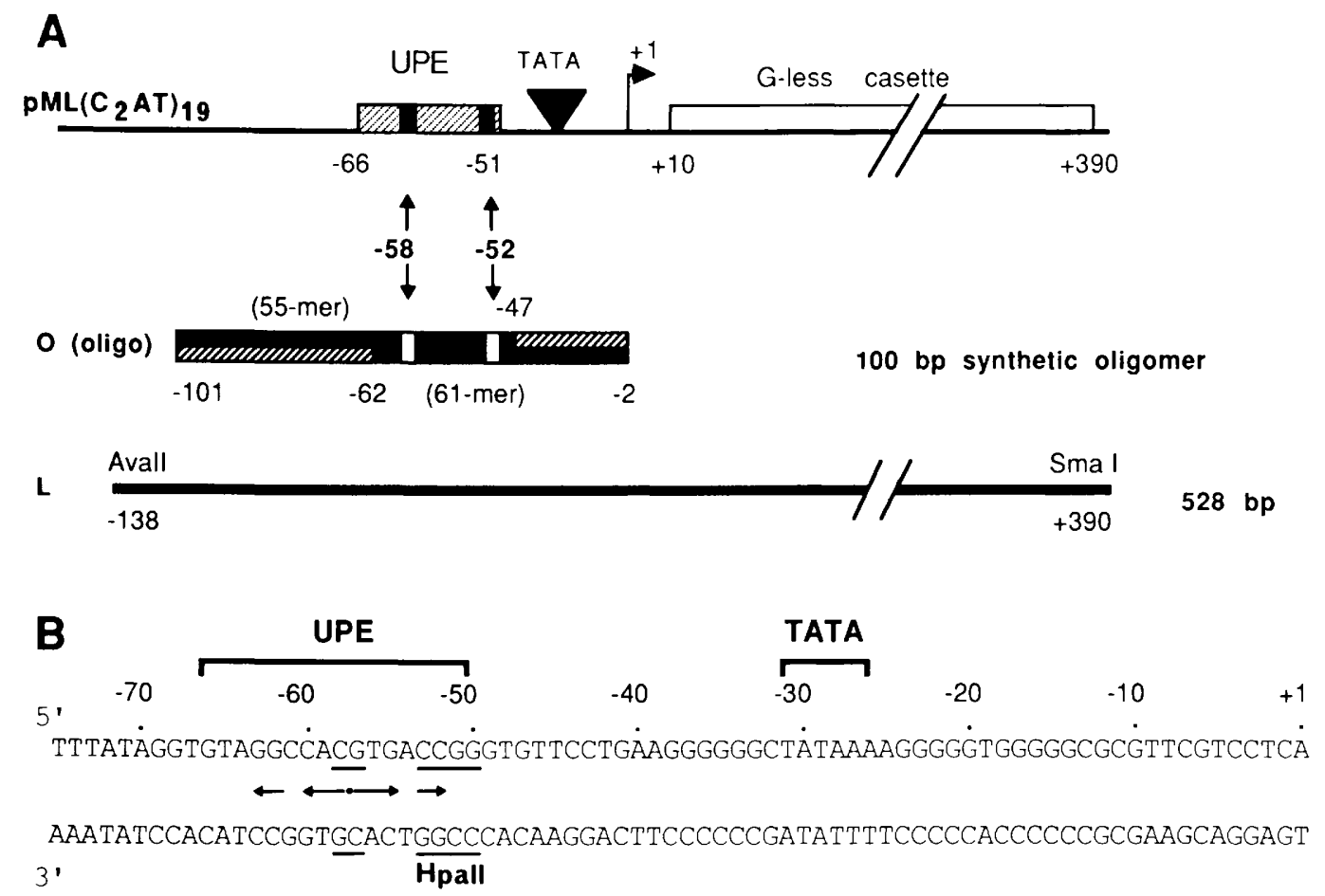

Figure 1. DNA fragments used for transcription factor-binding assays. $(A)$ The upper line shows a map of the plasmid $\mathrm{pML}\left(\mathrm{C}_{2} \mathrm{AT}\right)_{19}$, indicating the position of the TATA box and UPE relative to the transcription start site. The L restriction fragment is shown from the AvaII site $(-138)$ to the SmaI site $(+390)$. The O (oligonucleotide) fragments were made by end-filling two overlapping oligonucleotides, a 55 -mer (bases -101 to -47 ), and a 61 -mer (bases -62 to -2 ). (B) The sequence of the region upstream from the AdMLP transcription start site is shown. The arrows indicate a region of dyad symmetry. 


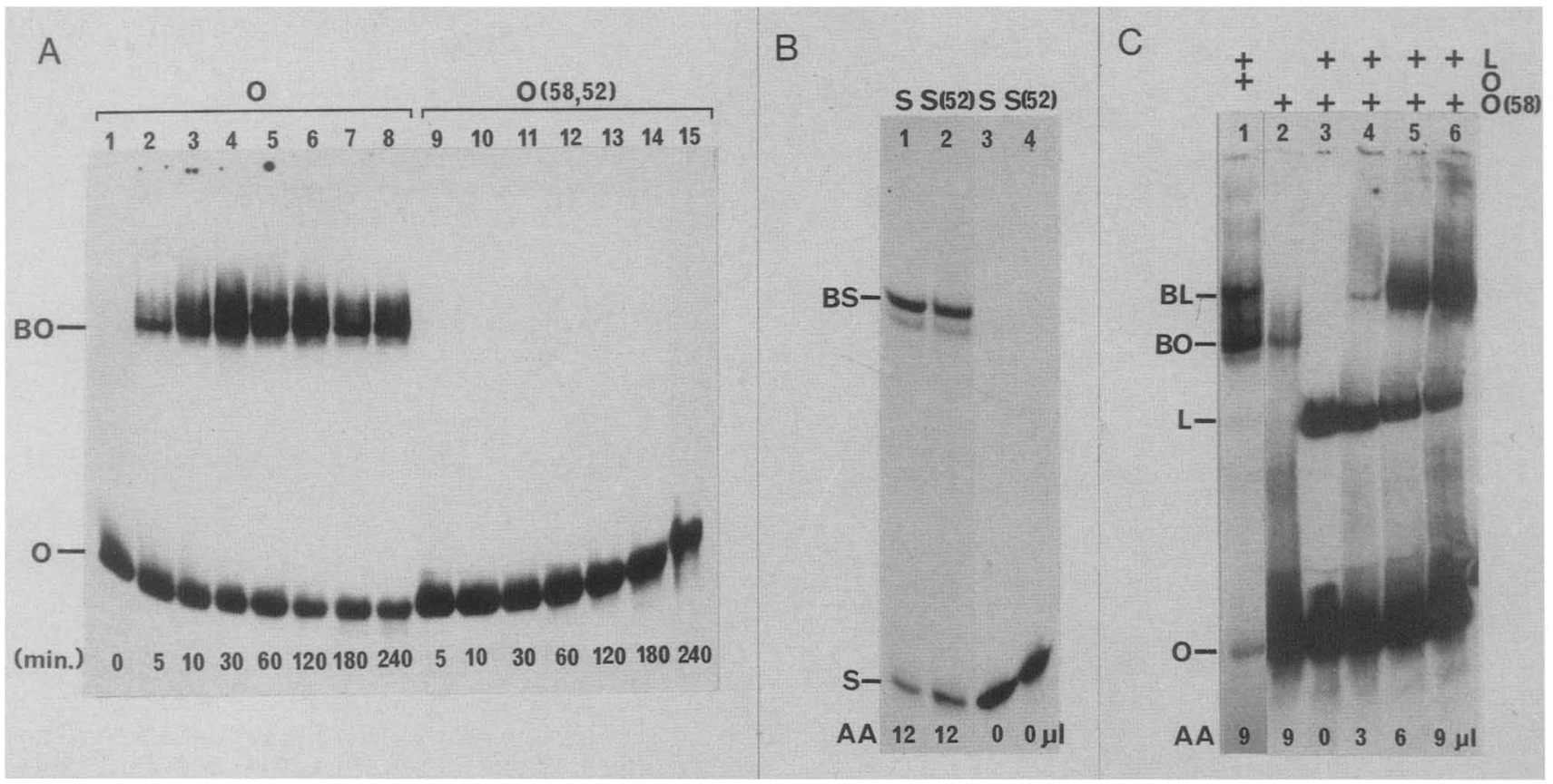

Figure 2. Effects of methylation of CpG sites at -58 and -52 on binding of MLTF. DNA fragments were incubated with a partially purified fraction (AA) containing MLTF, and the products were analyzed by a gel retardation assay. $(A)$ Binding reactions were done using unmethylated oligomer DNA $(\mathrm{O}$, lanes 2-8) or oligomer DNA methylated at both the -58 and -52 sites $[\mathrm{O}(58,52)$ lanes $9-15]$. Assays were done using $6 \mu \mathrm{l}$ of the AA fraction, and the time of incubation was varied from 5 to 240 min, as indicated. (Lane 1) Oligomer DNA incubated without the MLTF fraction; $(\mathrm{O}$ and $\mathrm{BO})$ the positions of free and bound oligomer DNA, respectively. (B) (Lanes 1 and 3) An unmethylated restriction fragment (S) extending from - 138 to -12 of the AdMLP; (lanes 2 and 4) the same fragment methylated at the $-52 \mathrm{CpG}$ site using $\mathrm{HpaIl}$ methylase [S(52)]. Incubations for lanes 1 and 2 contained $12 \mu \mathrm{l}$ and those for lanes 3 and 4 contained) $0 \mu \mathrm{l}$ of the AA fraction. (S) Free DNA; (BS) DNA-MLTF complex. (C) Mixtures of DNA fragments were incubated with the amounts of AA fraction indicated (bottom). DNAs contained in each incubation are indicated above the lanes. (L) A 528-bp unmethylated restriction fragment (see Fig. 1); (O) unmethylated 100-bp duplex oligonucleotide DNA; $[\mathrm{O}(58)]$ 100-bp duplex oligonucleotide DNA methylated at $-58 \mathrm{CpG}$ site. Complexes formed with the L fragment (BL) migrate more slowly than those formed with the oligomer DNA (BO). Lane 1 was run on a different gel from lanes 2-6. A long exposure for lanes 2-6 shows the formation of $\mathrm{BO}$ complex in the absence of the $\mathrm{L}$ fragment and the lack of this complex in the presence of the competing $\mathrm{L}$ fragment.

in the preparation of the methylated oligonucleotide DNA. When unmethylated oligomer DNA and the L fragment are incubated together with the AA fraction complexes formed on both DNAs, BO and BL, respectively, can be distinguished by their different electrophoretic mobility (Fig. 2C, lane 1). For DNA methylated at the -58 site (Fig. 2C), a low level of binding of MLTF is evident in the absence of competitor DNA (BO, lane 2). However, in the presence of the unmethylated DNA, there is no detectable binding of the methylated DNA even on the overexposed autoradiograph (Fig. 2C). In contrast, the unmethylated $\mathrm{L}$ fragment is bound efficiently in the presence of increasing amounts of MLTF.

A partially purified fraction (AA, Carthew et al. 1985) was used for the experiments shown in Figure 2. Similar effects of methylation at the $-58 \mathrm{CpG}$ site on binding of MLTF were seen when the factor had been purified further, $\sim 100$-fold, by sequence-specific DNA affinity chromatography (Fig. 3). The differential in binding was estimated by densitometry to be greater than 15 -fold.

Thus, methylation at a site central within the MLTFbinding site has a profound effect on its binding, whereas methylation at a site $6 \mathrm{bp}$ away on the edge of the binding site has little or no effect.

Because the daughter molecules are transiently methylated on only one strand in each round of replication, it was of interest to determine the binding characteristics of MLTF to DNA hemimethylated on either strand. MLTF was able to bind to both hemimethylated DNAs, though with reduced efficiency compared with the unmethylated DNA; methylation on the upper (noncoding) strand inhibited binding to a greater extent than methylation on the lower strand (Fig. 4, lanes 4-7 and 8-11). This indicates that steric hindrance by a single methyl group is not sufficient to prevent binding.

\section{Effect of $C p G$ methylation on transcription in vitro}

In vitro transcription in a HeLa whole-cell extract was used to determine whether the observed inhibition of MLTF binding is sufficient to inhibit transcription from the AdMLP. Oligonucleotide-directed mutagenesis of $\mathrm{pML}\left(\mathrm{C}_{2} \mathrm{AT}\right)_{19}$ was used to construct a plasmid, pMLRep, in which the sequences of the MLTF-binding site were replaced and flanking restriction sites introduced (Fig. 5). Following digestion with DraIII and StyI, methylated or 


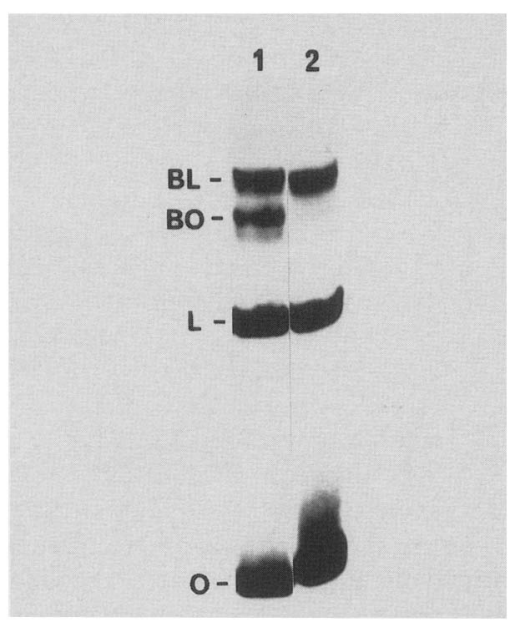

Figure 3. Gel retardation assay with affinity-purified MLTF. Mixtures of an unmethylated control fragment (L) and endfilled oligonucleotide DNA (O) were incubated with $6 \mu$ l of the MLTF fraction purified by sequence-specific DNA affinity chromatography. Complexes formed were analyzed by a gel retardation assay. (Lane 1) The oligonucleotide DNA was unmethylated; (lane 2) DNA was methylated at the $-58 \mathrm{CpG}$ site. (BL and $\mathrm{BO}$ ) Bound L fragment and oligonucleotide DNAs, respectively.

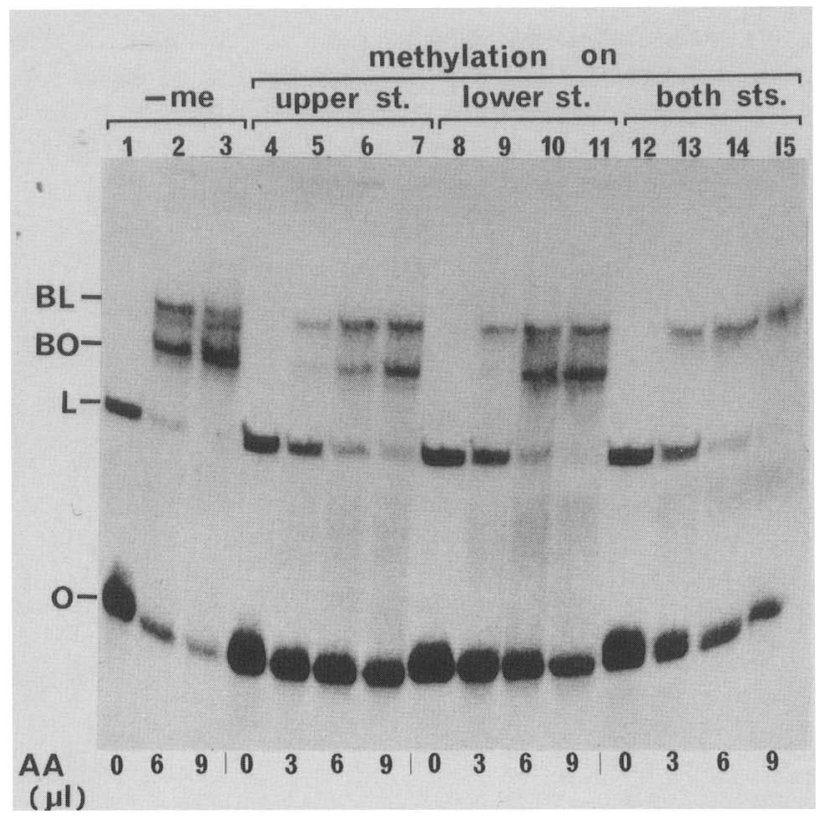

Figure 4. Binding of MLTF to hemimethylated DNAs. Singlestranded oligomers with or without methylation at the -58 site were annealed and end-filled to generate DNAs either unmethylated or methylated on the upper (noncoding), lower (coding), or both strands. Mixtures of the oligomers and L fragment $(1: 1$ molar ratio) were incubated with increasing amounts of the MLTF-containing fraction (AA, bottom). (Lanes 1-3) Unmethylated oligonucleotide DNA; (lanes 4-7) DNA methylated on the upper (noncoding) strand; (lanes 8-11) DNA methylated on the lower (coding) strand; (lanes 12-15) DNA methylated on both strands. unmethylated oligonucleotides were ligated to the vector, SmaI-EcoRI restriction fragments were purified, and concentrations were determined for transcription assays (see Materials and methods). The promoter sequence in these fragments differs from the AdMLP only by two base changes upstream of the MLTF-binding region, necessary to introduce the StyI site in pMLRep. Purified restriction fragments were assayed for transcription activity in the presence of a control template that produces a longer transcript. This acted as a control in case of inhibitors present in the gel-purified restriction fragments and for differential recoveries in the preparation of transcription products for electrophoresis. Transcription from the promoter methylated at the $\mathrm{CpG}$ site was substantially inhibited relative to that from the unmethylated promoter fragment (Fig. 5). Densitometry of different exposures of the gel indicated that inhibition due to methylation at the $-58 \mathrm{CpG}$ site was at least 5to 10 -fold when standardized against the internal control transcript. Similar results were obtained in another experiment using different preparations of restriction fragments in the transcription assays. This is consistent with only a low level of binding of MLTF to the methylated promoter as deletion of the MLTF-binding region has been shown to cause a decrease of 5- to 20 -fold in transcription from the AdMLP using whole-cell extracts (Hen et al. 1982; Jove and Manley 1984; Carthew et al. 1985; Miyamoto et al. 1985).

\section{Dissociation of DNA-MLTF complexes}

We have found that in the absence of $\mathrm{MgCl}_{2}$, MLTF binds more slowly to its target site to produce a 'loose' but stable complex that has the same electrophoretic mobility as the complex formed in the presence of $5 \mathrm{~mm}$ $\mathrm{MgCl}_{2}$ but in which the binding site is not protected from digestion with DNase I (Watt and Molloy 1988). Under these conditions, MLTF binds to the methylated DNA significantly better than in the presence of $\mathrm{MgCl}_{2}$ but still less efficiently than to the unmethylated DNA either in the presence or absence of $\mathrm{MgCl}_{2}$ (Fig. 6). It is therefore possible, in the absence of $\mathrm{MgCl}_{2}$, to form complexes of MLTF with DNA methylated at the -58 CpG site and then examine the dissociation of such complexes following addition of $\mathrm{MgCl}_{2}$ (conditions under which a low equilibrium level of binding is seen). Mixtures of either the unmethylated or methylated synthetic DNA with unmethylated L fragment (as an internal control) were incubated with MLTF in the absence of $\mathrm{MgCl}_{2}$ for $18 \mathrm{hr}$, followed by addition of $\mathrm{MgCl}_{2}$ to $5 \mathrm{~mm}$ and a 20-fold excess of unlabeled competitor DNA. MLTF dissociates from the L fragment and the unmethylated synthetic DNA at a similar rate (Fig. 6, lanes 1-4) with almost complete dissociation by 20 min. In contrast, the methylated DNA dissociates rapidly on addition of $\mathrm{MgCl}_{2}$, with none remaining bound after 2 min (lanes 5-8). Thus, methylation prevents formation of the 'tight' complex in which MLTF leaves a characteristic footprint on the DNA. 


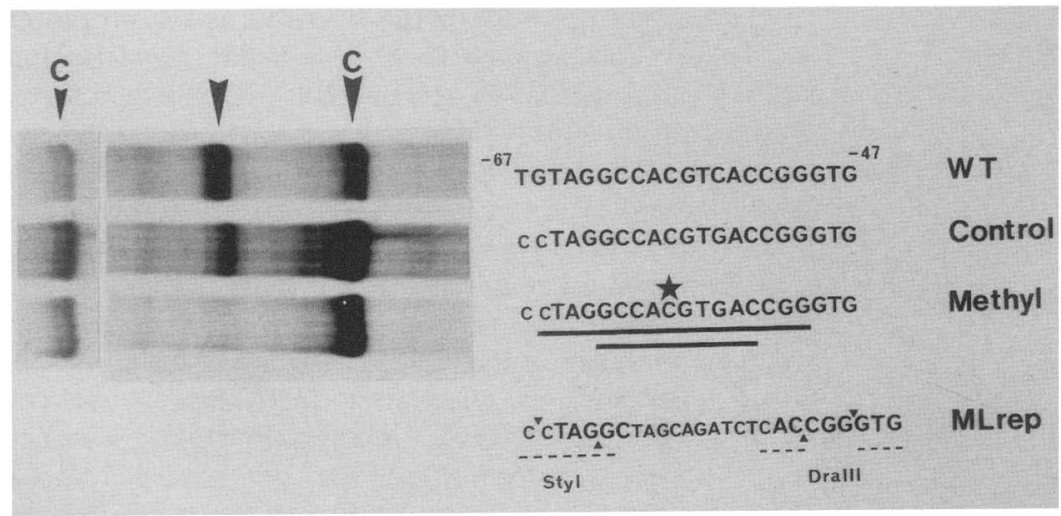

Figure 5. Methylation inhibits in vitro transcription. In vitro transcription reactions were done using as template DNAs $0.5 \mu \mathrm{g}$ of pAdMlp cut with BamHI (538-base transcript, labeled $\mathrm{C}$ ) and either $0.3 \mu \mathrm{g}$ of an EcoRI-SmaI fragment of pML $\left(\mathrm{C}_{2} \mathrm{AT}\right)_{19}(\mathrm{WT})_{\text {; }}$ $0.15 \mu \mathrm{g}$ of the EcoRI-SmaI fragment prepared by ligation of unmethylated oligonucleotides into pMLrep digested with DraIII and StyI (control); $0.15 \mu \mathrm{g}$ of methylated template DNA (methyl); or EcoRI-SmaI fragment, prepared by ligation of methylated oligonucleotides into pMLrep. A shorter autoradiographic exposure of the control transcripts is shown on the left. The sequences of the wild-

type AdMLP and the test promoters are shown; altered bases at positions -67 and -66 are shown as smaller letters. A star indicates the site of $\mathrm{CpG}$ methylation. The sequence regions covered by the upper and lower strand oligonucleotides used in template synthesis are indicated by the bars under the sequence. (Bottom) The sequence of the plasmid pMLrep in this region, with sites of cutting by StyI and DraIII indicated. Bases identical to those in $\mathrm{pML}\left(\mathrm{C}_{2} \mathrm{AT}\right)_{19}$ are shown as larger letters.

\section{Altered structure of methylated DNA}

Because the activity of DNase I on a given phosphodiester bond is dependent on the local phosphate geometry, it has been used as a probe for changes in the structure of DNA. The susceptibility to DNase I of the phos-

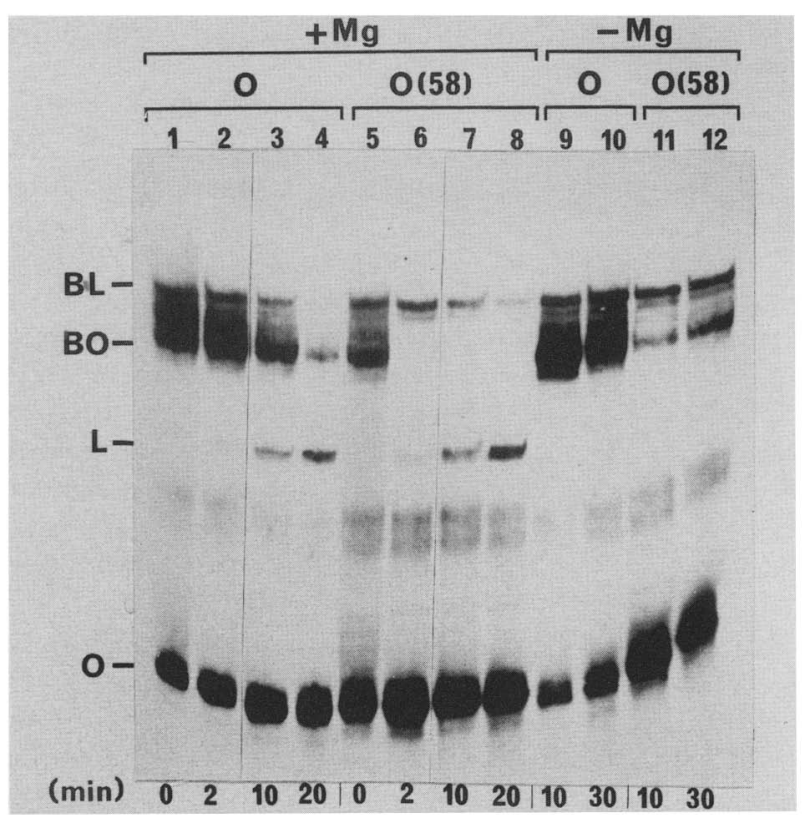

Figure 6. Dissociation of MLTF from methylated and unmethylated DNA. Mixtures of the L fragment and oligonucleotide DNA ( $1: 2$ molar ratio), either unmethylated $(\mathrm{O})$ or methylated at the -58 site $[\mathrm{O}(58)]$, were preincubated with the AA fraction $16 \mu \mathrm{l}$ in the absence of $\mathrm{MgCl}_{2}$, otherwise as in Materials and methods) for $18 \mathrm{hr}$ to allow maximum association of MLTF to DNAs. At time zero, a 20 -fold molar excess of unlabeled competitor DNA, $200 \mathrm{ng} \mathrm{pML}\left(\mathrm{C}_{2} \mathrm{AT}\right)_{19}$, was added. For incubations shown in lanes $1-8, \mathrm{MgCl}_{2}$ to $5 \mathrm{~mm}$ was also added. Incubations were done for 0 (no $\mathrm{MgCl}_{2}$ or competitor added), 2, 10, 20 , or $30 \mathrm{~min}$, as indicated. Samples were analyzed by polyacrylamide gel electrophoresis. $(\mathrm{O}, \mathrm{BO})$ Unbound and bound oligomer DNA, respectively; (L, BL) unbound and bound L fragment, respectively. phodiester bonds on both the coding and noncoding strands of unmethylated and methylated DNAs was therefore compared (Fig. 7).

Enhanced cutting of the phosphodiester bonds $5^{\prime}$ to the 5-methylcytosine bases on both strands and reduced cutting of the bonds $3^{\prime}$ to the guanosine bases of the CpG dinucleotide was seen. This result is analogous to that observed upon methylation of a GCGC sequence (Fox 1986) and indicates that the DNA methylation in both cases is causing a similar localized change in phosphate geometry. It has been suggested that methylation causes a rotation of the phosphates adjacent to the methylated cytosine (Fox 1986). Thus, it is possible that inhibition of MLTF binding could be due to a direct steric effect of the methyl groups in the major groove or to a secondary effect on the overall structure of the DNA.

\section{Discussion}

Methylation at a single CpG site $(-58)$ within the binding region for the transcription factor MLTF has been shown to strongly inhibit binding of the factor to DNA using an in vitro binding assay and to functionally inhibit transcription in an in vitro assay. The effect of methylation is highly site specific, as methylation at a site 6 bases away $(-52)$ has no demonstrable effect. Inhibition of transcription factor binding may therefore be an important mechanism by which DNA methylation is involved in the regulation of gene expression.

The CpG site at -58 in the AdMLP is located in a region that has been shown to be critical for binding and activity of MLTF. Single point mutations of $-59,-57$, -56 , and -55 all cause major reductions in activity, whereas point mutations at $-54,-51,-61,-62$, or -63 have lesser or no effects (Yu and Manley 1984; Miyamoto et al. 1985; Shi et al. 1986). Methylation interference studies indicate close major groove contacts between MLTF and guanine bases at positions -57 and -55 on the noncoding strand and $-60,-58$, and -53 on the coding strand (Carthew et al. 1987; Chodosh et al. 1987). Cytosine methylation is therefore probably like a mutation within the factor-binding site that lessens the 


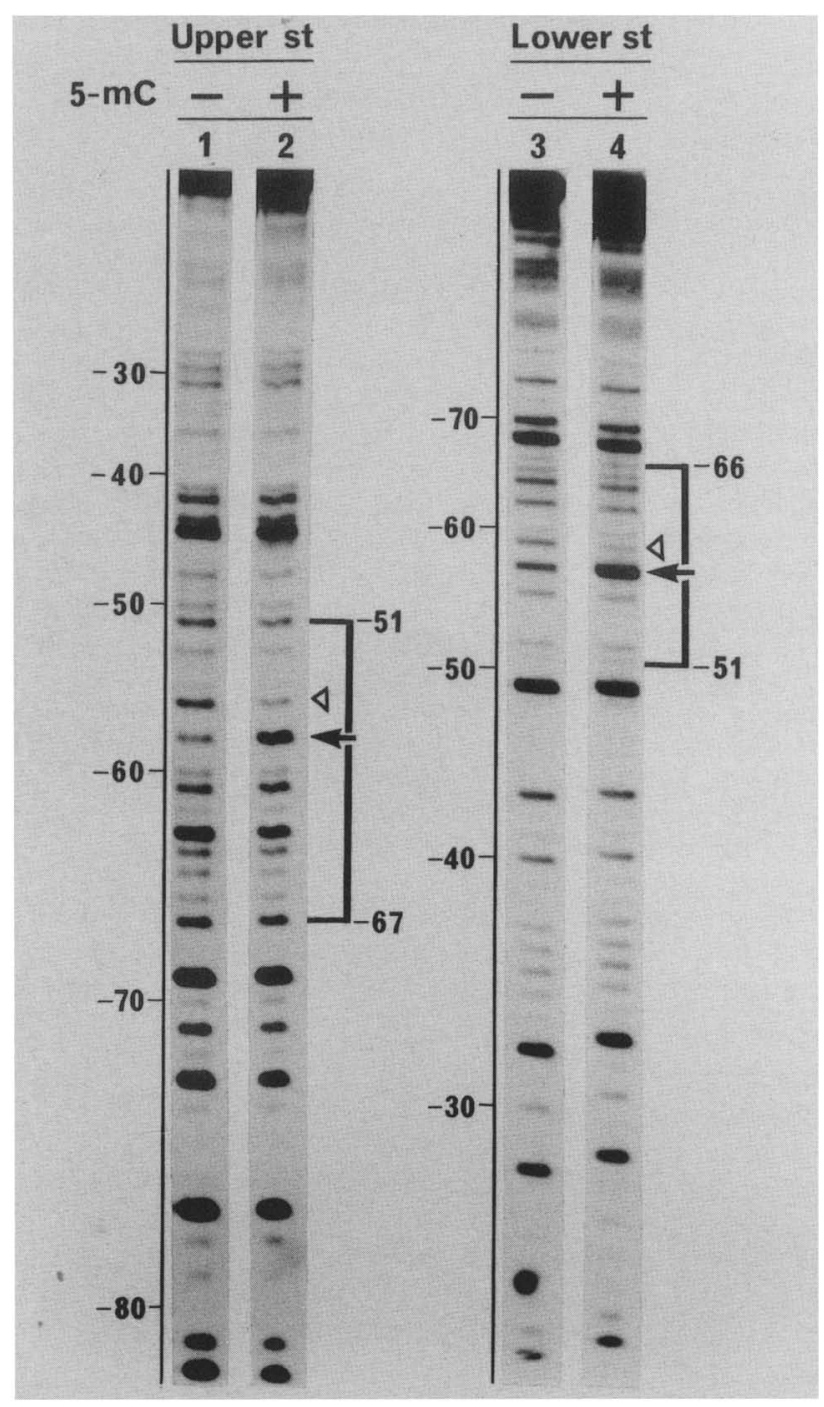

Figure 7. Effect of methylation on DNase I sensitivity. Methylated $(+)$ or unmethylated $|-|$ oligomer DNAs, 5 -end-labeled on the upper noncoding strand (upper st) or the lower coding strand (lower st) were subjected to partial digestion with DNase I. Digestion products were analyzed on a $10 \%$ denaturing polyacrylamide gel. UPE is indicated by brackets; arrows show sites of bonds with increased sensitivity, and open triangles show bonds of reduced sensitivity to DNase I. Bond numbers were derived by comparison of other DNase I digests with sequencing reactions (not shown).

ability of MLTF to bind. As similar inhibition is seen using MLTF purified by sequence-specific affinity chromatography, it is unlikely that methylation is acting here by promoting the binding of another factor that prevents MLTF binding. The rapid dissociation of MLTF from DNA methylated at the $-58 \mathrm{CpG}$ site on addition of $\mathrm{MgCl}_{2}$ (Fig. 6) is also consistent with a direct effect of methylation on MLTF binding. The inhibition of binding could be due to either direct steric interference by the methyl groups of essential recognition contacts in the major groove of the DNA or to localized changes in the helix geometry induced by methylation.

Recently it was shown that methylation of a single
CpG dinucleotide within the adenovirus E2 promoter also blocks binding of another cellular transcription factor $(E 2 F)$ and inhibits expression from the promoter in vivo (Kovesdi et al. 1987) and that methylation of a CpG site upstream of the rat tyrosine aminotransferase gene prevents the interaction of a specific factor with its binding site (Becker et al. 1987). In contrast, our preliminary results suggest that methylation of the CpG dinucleotide within the binding site for the factor SP1 has little effect on its binding (F. Watt and P. Molloy, unpubl.), and binding of another factor to the E2 promoter of adenovirus is also unaffected by methylation within the DNase I footprint region (Hoeveler and Doerfler 1987).

These data indicate that great care needs to be taken in interpreting correlations (or otherwise) between gene expression and the methylation status of particular restriction enzyme sites, such as HpaII and HhaI, even if they are within the promoter regions of genes. The finding that methylation within binding sites for specific transcription factors can inhibit their binding provides a new focus for examination of the role of DNA methylation in gene regulation during development. Clearly, it will be important to examine the state of methylation of CpG dinucleotides within the binding domains of such factors in promoters of normal cellular genes in relation to expression of the genes during normal development.

From studies of the transfection of DNA methylated in vitro using bacterial methyltransferases, it is clear that methylation can also inhibit transcription via less direct mechanisms than inhibiting transcription factor binding (e.g., see Buschhausen et al. 1985). This effect may be due to the preferential packaging of methylated DNA into an inactive chromatin configuration (Keshet et al. 1986).

Models for the involvement of DNA methylation in the regulation of gene expression during development require that mechanisms exist for demethylation at specific sites or regions in order to allow transcription to occur or to stabilize an active transcriptional state. Where the process of demethylation has been studied, demethylation events have been localized to transcription factor (estradiol and glucocorticoid) binding sites (Saluz et al. 1986) or to specific sites within promoters (Yisraeli et al. 1986; Shimada et al. 1987). That MLTF can bind with reasonable, though reduced, efficiency to hemimethylated DNA is interesting with regard to possible mechanisms of demethylation. For example, following DNA replication, MLTF could bind to hemimethylated DNA (perhaps with some degree of strand preference) and potentially prevent access of the maintenance hemimethylase to the site. This could lead to production of a fully unmethylated DNA through an active process or at the next round of replication and, hence, conversion of a low-affinity binding site to a high-affinity one.

Thus, methylation at a single CpG dinucleotide centrally located within the binding site for the transcription factor MLTF is sufficient to prevent specific binding 
of the factor to DNA under normal assay conditions. Methylation at a second CpG site located only 6 bases $3^{\prime}$ to this site has no discernible effect on binding. DNA methylated at the central site on one strand only binds MLTF with reduced efficiency compared with unmethylated DNA, the effect being greater for DNA methylated on the noncoding strand. The results clearly indicate that in some cases DNA methylation may inhibit transcription by directly blocking the binding of a transcription factor.

As exemplified here, the approach of incorporation of modified nucleosides into factor-binding sites during oligonucleotide synthesis is clearly applicable to the detailed study of many protein-DNA interactions.

\section{Materials and methods}

Plasmids and DNA fragments

Restriction enzyme fragments containing the AdMLP were isolated by digestion of the plasmid pML $\left(\mathrm{C}_{2} \mathrm{AT}\right)_{19}$ (Sawadogo and Roeder 1985b).

The $\mathrm{L}$ fragment was isolated from a $6 \%$ acrylamide gel following digestion with AvaII and SmaI and 3 ' end labeling of the Avall site (Maniatis et al. 1982). Similarly, the S fragment (nucleotides -138 to -12 ) was isolated following digestion with AvalI and HhaI. HpaIl-methylated restriction fragments were isolated from plasmid DNA methylated with Hpall methylase according to the supplier's (New England Biolabs) instructions. DNA was $>95 \%$ methylated, as judged by resistance to cleavage by HpaII. Oligonucleotides were synthesized using an Applied Biosystems 380A DNA Synthesizer and reagents from the same company. For synthesis of methylated oligonucleotides, 5-methylcytidine phosphoramidite replaced cytidine phosphoramidite at either the $-58 \mathrm{CpG}$ site or at both the -58 and $-52 \mathrm{CpG}$ sites. Duplex DNAs (100 bp) were synthesized by mixing 1 pmole each of appropriate oligonucleotides in $20 \mu \mathrm{l}$ of $10 \mathrm{~mm}$ Tris- $\mathrm{HCl}(\mathrm{pH} 7.5), 50 \mu \mathrm{M} \mathrm{NaCl}_{2}, 1 \mathrm{~mm}$ dithiothreitol (DTT), $50 \mu \mathrm{M}$ each of dCTP, dTTP, and dGTP, and $10 \mu \mathrm{Ci}$ of $\left[\alpha^{-32} \mathrm{P}\right] \mathrm{dATP}(2000 \mathrm{Ci} / \mathrm{mmole})$. One unit of the Klenow fragment of DNA polymerase I was added, and after incubation at room temperature for $20 \mathrm{~min}$, a chase of $50 \mu \mathrm{M}$ dATP and a further unit of the Klenow fragment were added and incubation continued for $10 \mathrm{~min}$ at $37^{\circ} \mathrm{C}$. Duplex DNA was purified by gel electrophoresis. Both $\left[\alpha^{-32} \mathrm{P}\right] \mathrm{dATP}$ and $\left[\alpha^{-32} \mathrm{P}\right] \mathrm{dCTP}$ were used for some preparations.

Plasmid pMLRep was derived from pML $\left./ \mathrm{C}_{2} \mathrm{AT}\right)_{19}($ Sawadogo and Roeder 1985b) by oligonucleotide-directed mutagenesis, following subcloning of an EcoRI-Pst fragment into M13mp9. The altered promoter was then recloned into pUC18 as an EcoRI-PstI fragment. The sequence of pMLRep is identical to $\mathrm{pML}\left(\mathrm{C}_{2} \mathrm{AT}\right)_{19}$, except for the altered bases indicated in Figure 5. Restriction fragments for transcription assays were made as follows. pMLRep was digested with StyI and DraIII; and the small excised fragment was removed using NACS (BRL) chromatography following phenol extraction and ethanol precipitation. Methylated or unmethylated oligonucleotides corresponding to the upper $\left(5^{\prime}\right.$-CTAGGCCACGTGACCGG) or lower (5'-GTCACGTGGC) strands of the promoter, 100 pmole of each, were mixed with the DNA and ligated overnight at $16^{\circ} \mathrm{C}$ in $100-\mu \mathrm{l}$ reactions. The ligated DNA was cut with EcoRI and SmaI, and the 800-bp fragment containing the AdMLP and $\mathrm{G}$-less cassette was isolated following electrophoresis in low melting point agarose. Quantities of recovered DNA were determined by comparison with standards, both in agarose gels and following hybridization of dilution series of the DNAs with a kinased 61-mer oligonucleotide (see Fig. 1).

\section{Factor preparation and in vitro transcription reactions}

MLTF was partially purified from a whole-cell HeLa transcription lysate as the successive flowthrough fractions from phosphocellulose and DEAE-Sephacel columns, as described by Carthew et al. (1985). This MLTF-containing fraction (AA) gives the expected footprint on the UPE region. The protein concentration of the AA fraction was $1.5 \mathrm{mg} / \mathrm{ml}$, as determined using a Bio-Rad protein assay kit. For the assay shown in Figure 3, MLTF was further purified by DNA affinity chromatography. DNA Sepharose 4B was prepared according to the method of Kadonaga and Tjian (1986) using 19-mer oligonucleotide to give the sequence $5^{\prime}$-(GATC)CGAATCCACGTGACG|GATC) 3'. The AA fraction was incubated with the affinity resin for $1 \mathrm{hr}$ at $30^{\circ} \mathrm{C}$ in buffer $\mathrm{A}$ (12 $\mathrm{mm}$ hydroxypiperazine (HEPES), $0.6 \mathrm{mM}$ EDTA, $0.6 \mathrm{~mm}$ DTT, $12 \%$ glycerol, $0.1 \mathrm{mg} / \mathrm{ml}$ bovine serum albumin (pH 7.9)] containing $5 \mathrm{mM} \mathrm{MgCl}_{2}, 60 \mathrm{mM} \mathrm{KCl}$, and 10 $\mathrm{mg} / \mathrm{ml}$ poly $(\mathrm{dI}-\mathrm{dC}) \cdot(\mathrm{dI}-\mathrm{dC})$. The incubation mixture was packed in a column and washed with 7.5 column volumes of buffer A containing $60 \mathrm{mM} \mathrm{KCl}$, followed by step elutions of 7.5 column volumes each with buffer A containing $0.5 \mathrm{M} \mathrm{KCl}$ and then buffer A containing $1 \mathrm{M} \mathrm{KCl}$. MLTF from the $1 \mathrm{M} \mathrm{KCl}$ elution step was used for binding assays.

From comparisons on SDS-polyacrylamide gels, it was estimated that an equivalent amount of protein from the affinitypurified preparation (excluding bovine serum albumin present in the elution buffer) had 100-200 times the binding activity of the AA fraction.

Whole-cell HeLa transcription lysate was prepared and transcription reactions were done as described previously (Tremethick and Molloy 1986).

\section{Factor-binding assays}

Reactions of $20 \mu \mathrm{l}$ contained $\sim 4$ fmoles of labeled DNA fragment, $500 \mathrm{ng}$ of poly $(\mathrm{dI}-\mathrm{dC}) \cdot(\mathrm{dI}-\mathrm{dC})$, and 3-12 $\mu \mathrm{l}$ of the MLTFcontaining fraction (AA). Final buffer conditions were $12 \mathrm{mM}$ HEPES, $60 \mathrm{mM} \mathrm{KCl}, 5 \mathrm{~mm} \mathrm{MgCl} 2,0.6 \mathrm{~mm}$ EDTA, $12 \%$ glycerol, and $0.6 \mathrm{mM}$ DTT $\left(\mathrm{pH} 7.9\right.$ ). Incubations were at $30^{\circ} \mathrm{C}$ for $40 \mathrm{~min}$ or at times shown. Samples were loaded onto a $4 \%$ polyacrylamide gel $(80: 1$ acrylamide/bis-acrylamide) run in $6.7 \mathrm{~mm}$ Tris, $3.3 \mathrm{~mm}$ sodium acetate, and $1 \mathrm{mM}$ EDTA $(\mathrm{pH} 7.9)$ at $4^{\circ} \mathrm{C}$ with recirculation of buffer. Estimates of relative binding or transcription activity were made following densitometry of appropriate autoradiographs on a Biomed Soft Laser densitometer.

\section{DNase I digestions}

Oligonucleotides were $5^{\prime}$-end-labeled using $\left[\gamma^{32}\right.$ P]ATP and polynucleotide kinase (Maniatis et al. 1982). Duplex DNA was made by annealing a labeled and an unlabeled oligonucleotide and end-filling as above, except that all deoxynucleotides were present at $50 \mu \mathrm{M}$. DNAs were purified by gel electrophoresis. DNase I digestions were done for $4 \mathrm{~min}$ at $30^{\circ} \mathrm{C}$ using 0.05 units of DNase I (Promega RQ1 DNase) and $10 \mathrm{ng}$ of DNA in $40-\mu \mathrm{l}$ reactions. The reaction buffer was $100 \mathrm{~mm}$ Tris- $\mathrm{HCl}(\mathrm{pH} 7.5)$, and $10 \mathrm{mM} \mathrm{MgCl}_{2}$.

\section{Acknowledgments}

We wish to thank Dr. Gerry Both for synthesis of oligodeoxynucleotides, Jenny Tallon for technical assistance, and Drs. G. 
Grigg, H. Drew, G. Both, and M. Frommer for critical reading and comments on the manuscript.

\section{References}

Becker, P.B., S. Ruppert, and G. Schutz. 1987. Genomic footprinting reveals cell type-specific DNA binding of ubiquitous factors. Cell 51: 435-443.

Buschhausen, G., M. Graessmann, and A. Graessmann. 1985. Inhibition of herpes simplex thymidine kinase expression by DNA methylation is an indirect effect. Nucleic Acids Res. 13: $5503-5513$.

Busslinger, M., J. Hurst, and R.A. Flavell. 1983. DNA methylation and the regulation of globin gene expression. Cell 34: 197-206.

Carthew, R.W., L.A. Chodosh, and P.A. Sharp. 1985. An RNA polymerase II transcription factor binds to an upstream element in the adenovirus major late promoter. Cell 43: 439448.

- 1987. The major late transcription factor binds to and activates the mouse metallothionein I promoter. Genes Dev. 1: 973-980.

Cedar, H. 1984. DNA methylation and gene expression. In DNA methylation: biochemistry and biological significance (ed. A. Razin, H. Cedar, and A. Riggs), pp. 147-164. Springer Verlag, New York.

Chodosh, L.A., R.W. Carthew, J.G. Morgan, G.R. Crabtree, and P.A. Sharp. 1987. The adenovirus major late transcription factor activates the rat $\gamma$-fibrinogen promoter. Science 238: 684-688.

Doerfler, W. 1983. DNA methylation and gene activity. Annu. Rev. Biochem. 52: 93-124.

Feenstra, A., J. Fewell, K. Leuders, and E. Kuff. 1986. In vitro methylation inhibits the promoter activity of a cloned intracisternal A-particle LTR. Nucleic Acids Res. 14: 43434352.

Fox, K.R. 1986. Effect of HhaI methylation on DNA local structure. Biochem. I. 234: 213-216.

Hen, R., P. Sassone-Corsi, J. Corden, M.P. Gaub, and P. Chambon. 1982. Sequences upstream of the TATA box are required in vivo and in vitro for efficient transcription from the adenovirus serotype 2 major late promoter. Proc. Natl. Acad. Sci. 79: 7132-7136.

Hoeveler, R. and W. Doerfler. 1987. Specific factors binding to the late E2A promoter region of adenovirus type 2 DNA: no apparent effects of 5'-CCGG-3' methylation. DNA 6: 449460.

Jove, R. and J.L. Manley. 1984. In vitro transcription from the adenovirus 2 major late promoter utilizing templates truncated at promoter-proximal sites. J. Biol. Chem. 259: 85138521.

Jove, R., D. Sperber, and J.L. Manley. 1984. Transcription of methylated eukaryotic viral genes in a soluble in vitro system. Nucleic Acids Res. 12: 4715-4730.

Kadonaga, J.T. and R. Tjian. 1986. Affinity purification of sequence-specific DNA binding proteins. Proc. Natl. Acad. Sci. 83: 5889 -5893.

Keshet, I., J. Lieman-Hurwitz, and H. Cedar. 1986. DNA methylation affects the formation of active chromatin. Cell 44: $535-543$.

Keshet, I., J. Yisraeli, and H. Cedar. 1985. Effect of regional DNA methylation on gene expression. Proc. Natl. Acad. Sci. 82: $2560-2564$.

Kovesdi, I., R. Reichel, and J.R. Nevins. 1987. Role of an adenovirus E2 promoter binding factor in EIA-Mediated coordinate gene control. Proc. Natl. Acad. Sci. 84: 2180-2184.
Kruczek, I. and W. Doerfler. 1983. Expression of the chloramphenicol acetyltransferase gene in mammalian cells under the control of adenovirus type 12 promoters: effect of promoter methylation on gene expression. Proc. Natl. Acad. Sci. 80: 7586-7590.

Langner, K.-D., L. Vardimon, D. Renz, and W. Doerfler. 1984. DNA methylation of three $5^{\prime}$ C-C-G-G $3^{\prime}$ sites in the promoter and $5^{\prime}$ region inactivate the E2a gene of adenovirus type 2. Proc. Natl. Acad. Sci. 81: 2950-2954.

Maniatis, T., E.F. Fritsch, and J. Sambrook. 1982. Molecular cloning: A laboratory manual (ed. T. Maniatis, E.F. Fritsch, and J. Sambrook), Cold Spring Harbor Laboratory, Cold Spring Harbor, New York.

McKnight, S. and R. Tiian. 1986. Transcriptional selectivity of viral genes in mammalian cells. Cell 46: 795-805.

Miyamoto, N.G., V. Moncollin, J.M. Egly, and P. Chambon. 1985. Specific interaction between a transcription factor and the upstream element of the adenovirus 2 major late promoter. EMBO I. 4: 3563-3570.

Miyamoto, N.G., V. Moncollin, M. Winterzerith, R. Hen, J.M. Egly, and P. Chambon. 1984. Stimulation of in vitro transcription by the upstream element of the adenovirus 2 major late promoter involves a specific factor. Nucleic Acids Res. 12: $8779-8799$.

Saluz, H.P., J. Jiricny, and J.P. Jost. 1986. Genomic sequencing reveals a positive correlation between the kinetics of strandspecific DNA demethylation of the overlapping estradiol/ glucocorticoid-receptor binding sites and the rate of avian vitellogenin mRNA synthesis. Proc. Natl. Acad. Sci. 83: 7167-7171.

Sawadogo, M. and R.G. Roeder. 1985a. Interaction of a genespecific transcription factor with the adenovirus major late promoter upstream of the TATA box region. Cell 43: 165175.

175. 1985b. Factors involved in specific transcription by human RNA polymerase II: analysis by a rapid and quantitative in vitro assay. Proc. Natl. Acad. Sci. 82: 4394-4398.

. 1986. DNA binding specificity of USF, a human genespecific transcription factor required for maximum expression of the major late promoter of adenovirus. In Cancer cells: DNA tumor viruses, vol. 4, pp. 147-154. Cold Spring Harbor Laboratory, Cold Spring Harbor, New York.

Shi, X.-P., R. Lee, and R. Weinmann. 1986. Protein factors binding independently to two different regions of the adenovirus 2 major late promoter. Nucleic Acids Res. 14: 37293744.

Shimada, T., K. Inokuchi, and A.W. Nienhuis. 1987. Site-specific demethylation and normal chromatin structure of the human dihydrofolate reductase gene promoter after transfection into CHO cells. Mol. Cell. Biol. 7: 2830-2837.

Tremethick, D.J. and P.L. Molloy. 1986. High mobility group proteins 1 and 2 stimulate transcription in vitro by RNA polymerases II and III. J. Biol. Chem. 261: 6986-6992.

Watt, F. and P.L. Molloy. 1988. High mobility group proteins 1 and 2 stimulate binding of a specific transcription factor to the adenovirus major late promoter. Nucleic Acids Res. 16: $1471-1486$.

Yamamoto, K. 1985. Steroid receptor regulated transcription of specific genes and gene networks. Annu. Rev. Genet. 19: $209-252$.

Yisraeli, J., R.S. Adelstein, D. Melloul, U. Nudel, D. Yaffe, and H. Cedar. 1986. Muscle-specific activation of a methylated chimeric actin gene. Cell 46: 409-416.

Yu, Y.-T. and J.L. Manley. 1984. Generation and functional analyses for base-substitution mutants of the adenovirus-2 major late promoter. Nucleic Acids Res. 12: 9309-9321. 


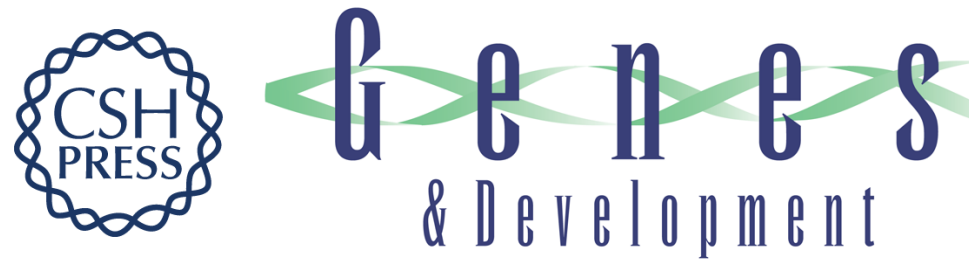

\section{Cytosine methylation prevents binding to DNA of a HeLa cell transcription factor required for optimal expression of the adenovirus major late promoter.}

F Watt and P L Molloy

Genes Dev. 1988, 2:

Access the most recent version at doi:10.1101/gad.2.9.1136

References This article cites 32 articles, 14 of which can be accessed free at: http://genesdev.cshlp.org/content/2/9/1136.full.html\#ref-list-1

License

Email Alerting Service

Receive free email alerts when new articles cite this article - sign up in the box at the top right corner of the article or click here.

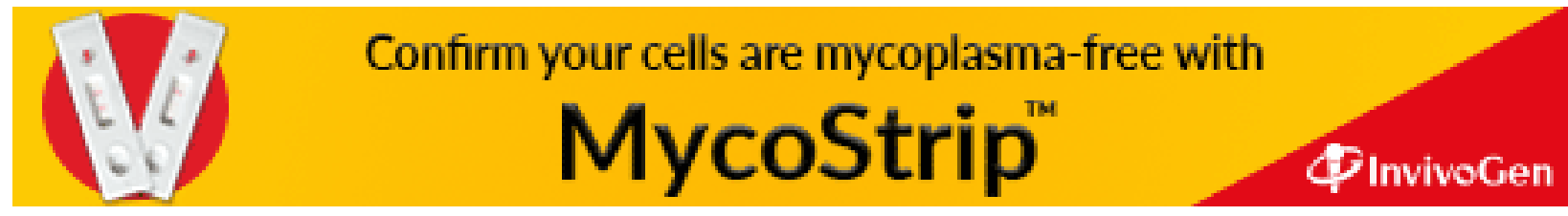

